\title{
The Incarnation of the Free Spirits in Nietzsche: A Continuum of Triple Dialectic
}

\section{Alexis Deodato S. Itao}

\begin{abstract}
Most studies on Nietzsche seldom associate him with the dialectic method. We readily think of Socrates, Hegel, and Marx when we hear of dialectic, but very rarely, if at all, of Nietzsche. To date, very few studies on Nietzsche have claimed that one of the German philosopher's underpinning philosophical methodologies in his literary oeuvre is the dialectic. This paper thus intends to show that Nietzsche has been employing the dialectic throughout his writings, especially in his treatment of the "free spirits" - a recurring subject in his different compositions. To do this, I will first revisit the meaning of dialectic in Socrates, Hegel, and Marx and subsequently argue that in Nietzsche, a type of dialectic akin to Hegel's permeates his writings. In the next parts of this paper, I will discuss in-depth how for Nietzsche, the incarnation of the free spirits involves not just one, but a continuum of triple dialectic. I will argue that to become a free spirit, one must constantly apply the dialectics of (1) criticality and openness, (2) unlearning and relearning, and (3) overcoming and becoming. These dialectics, in my view, are the necessary conditions for any individual to be truly free. In this paper, I will importantly highlight that these dialectics run through Nietzsche's works starting from the early up to the final period of his literary productivity.
\end{abstract}

Keywords: Nietzsche, free spirits, dialectic, overman

\section{The Meaning of Dialectic in Socrates, Hegel, and Marx}

$\mathrm{M}$ ost studies on Friedrich Wilhelm Nietzsche (1844-1900) seldom associate him with the dialectic method. We readily think of Socrates, Hegel, and Marx when we hear of dialectic, but very rarely, if at all, of Nietzsche. To date, very few studies on Nietzsche have claimed that one of the German philosopher's underpinning philosophical 
methodologies in his literary oeuvre is the dialectic. ${ }^{1}$ This paper thus intends to show that Nietzsche has been employing the dialectic throughout his writings, especially in his treatment of the "free spirits" - a recurring subject in his different compositions. To do this, I will first revisit the meaning of dialectic in Socrates, Hegel, and Marx and subsequently argue that in Nietzsche, a type of dialectic akin to Hegel's permeates his writings.

I begin with Socrates (ca. 470 B.C.E.-399 B.C.E.), the first Western philosopher who popularized dialectic. ${ }^{2}$ To this day, scholars offer different interpretations on Socrates's purpose of dialectic. Some interpretations say that Socrates used dialectic to simply refute someone's errors; others say that he merely used it as a means to show the inconsistency in someone's set of beliefs. However you interpret the Socratic dialectic, it always results into the same outcome: that is, something which has previously been held as correct is now shown to be incorrect after all. ${ }^{3}$ In other words, dialectic for Socrates was more of a special method of dialogue through which one gradually arrives at the knowledge of truth or, in Platonic language, the Forms. But then, because it starts off by rejecting or disproving someone's truth-claims, Socrates' use of dialectic is characteristically negative. It proceeds by negating, by showing that someone is on the wrong side. In fact, that was why Socrates was sentenced to death: many hated him and wanted him dead because he had humiliated them during one of his dialectical intercourses with them.

In Georg Wilhelm Friedrich Hegel (1770-1831), dialectic takes on a different meaning. Instead of seeing dialectic as a pure method of dialogue, Hegel sees dialectic as "the experience of consciousness." 4 That is to say,

${ }^{1}$ The only studies that I personally know include: (1) Brian Wetstein, "The Role of Dialectic in Nietzsche's Thought" (Ph.D. Dissertation, University of Guelp, 1994). Wetstein claims that Nietzsche, throughout his writings, consistently employed a kind of dialectic that suggests that it could be a methodological principle that he followed. (2) John Richardson, Nietzsche's System (Oxford: Oxford University Press, 1996). Richardson believes that within Nietzsche's "system" of philosophizing, there is a certain dialectic which Nietzsche often employed. (3) Walter A. Kaufmann, "Nietzsche's Admiration for Socrates," in Journal of the History of Ideas, 9:4 (October 1948), 472-491. Kaufmann, it should be noted, was one of the earliest and most respected translators of Nietzsche's writings to English. In being so familiar with Nietzsche, even Kaufmann himself could not help but conclude that Nietzsche is "a dialectical thinker" from The Birth of Tragedy up to his later writings. See ibid., 482.

2 According to Aristotle, Socrates was not the one who first invented dialectic. It was rather Zeno of Elea, the pre-Socratic philosopher who was known as a follower of Parmenides. For details see Wolfgang Kullmann, "Aristotle's Gradual Turn from Dialectic," in The Development of Dialectic from Plato to Aristotle, ed. by Jakob Lith Fink (Cambridge: Cambridge University Press, 2012), 296.

${ }^{3}$ John Beverluis, "Socrates," in The World's Great Philosophers, ed. by Robert L. Arrington (Oxford: Blackwell Publishing, 2003), 305.

${ }^{4}$ Hegel quoted in Frederick C. Beiser, "Introduction: Hegel and the Problem of Metaphysics," in The Cambridge Companion to Hegel, ed. by Frederick C. Beiser (Cambridge:

(C) 2018 Alexis Deodato S. Itao

https://www.kritike.org/journal/issue 22/itao june2018.pdf

ISSN 1908-7330

(cc) BY-NC-ND 


\section{A CONTINUUM OF TRIPLE DIALECTIC}

dialectic is that method that brings to light how consciousness works and develops, for example when we form concepts, judgments, and syllogisms. ${ }^{5}$ Since for Hegel, our various concepts, judgments, and propositions constitute the categories of consciousness, the primary function of dialectic is to expose the inherent self-contradictory character of these very categories. At the same time, dialectic is also what reconciles these categories by developing another set of categories. ${ }^{6}$ However, after these categories are reconciled, their dynamic nature will later on generate a new tension, such that they again have to be reconciled. This continuous process of tension and reconciliation is how dialectic proceeds. ${ }^{7}$ There is another important category which Hegel himself gave as an example to illustrate the general sense of his dialectic method. It is the category of Being, whose opposite is Nothing. ${ }^{8}$ In Hegel's view, their opposition can be reconciled by another category: Becoming. "Becoming then," says Michael Forster, "forms the starting point for a new round of the dialectic." 9 To put it simply, whatever is (Being) is always opposed by whatever is not (Nothing). And in between the two, there always exists a link that is neither "isness" nor "nothingness," i.e., Becoming. This is Hegel's dialectic method in general: a system that can be used to explain not only the development of consciousness but also the relationships of things in the world and the direction of human history. It is similar to that of Socrates in that it culminates at the knowledge of truth or, to use Hegel's own term, the Absolute Idea. ${ }^{10}$ Hegel's dialectic, then, is teleological since it involves a continuous process of progression towards truth. And like Socrates's, Hegel's dialectic also involves some form of negation, where what is claimed to be true is always opposed by a counter-claim and always shown to be just one side of the whole reality.

Karl Heinrich Marx's (1818-1883) conception of dialectic is heavily influenced by Hegel's. Marx employed the dialectic in his theory of history as a lens with which to view the incessant economic movements and political changes in the material world. He underscores, for example, the relationship between the capitalists and the proletariat: a contradiction that can only be resolved with the dissolution of the two. And yet even if the two would be dissolved, a new generation of capitalists and proletariat would still arise once more. This is Marx's dialectical reading of the movement of history.

Cambridge University Press, 1993), 20. Hegel also used the term mind or spirit (Geist) to refer to consciousness.

${ }^{5}$ Michael Forster, "Hegel's Dialectical Method," in The Cambridge Companion to Hegel, 132

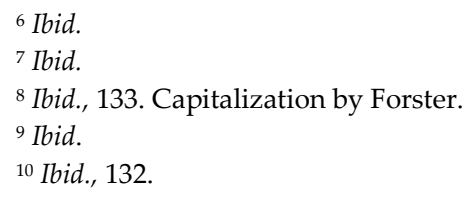

(C) 2018 Alexis Deodato S. Itao https://www.kritike.org/journal/issue 22/itao june2018.pdf ISSN 1908-7330 
Dialectic for Marx is both an instrument to better understand the movement of history and the very dynamic of history's movement itself. ${ }^{11}$

\section{Recovering the Nietzschean Dialectic}

Since Gilles Deleuze published his Nietzsche and Philosophy in 1962, subsequent Nietzsche scholars have been "Deleuzed" into thinking that Nietzsche was never a dialectician both in the Socratic and Hegelian sense. As Deleuze himself puts it, "Nietzsche presents the dialectic as the speculation of the pleb, as the way of thinking of the slave .... [because] [t]he dialectic presents a certain conception of the tragic: linking it to the negative, to opposition and to contradiction." 12 But according to Francesca Cauchi, more and more scholars have expressed their disagreement with Deleuze. ${ }^{13}$ Cauchi relates that Deleuze arrived at his interpretation of Nietzsche as contra dialectic because all along he was doing "an emphatically antiHegelian reading of Nietzsche." 14 And yet, Hegel does not really stand opposed to Nietzsche. Cauchi insists that their philosophies are consonant to one another. Nietzsche, in fact, follows Hegel's system of dialectic because in Nietzsche, there is a dialectic which is quite similar to Hegel's. ${ }^{15}$

Already in The Birth of Tragedy, ${ }^{16}$ Nietzsche shows a penchant for Hegelian dialectic, especially in his overall treatment of the relationship

\footnotetext{
${ }^{11}$ For a succinct discussion of Marx's philosophy, see Peter Singer, Marx: A Very Short Introduction (Oxford: Oxford University Press, 1996).

12 Gilles Deleuze, Nietzsche and Philosophy, trans. by Hugh Tomlinson (New York: Colombia University Press, 2006), 10-11.

${ }^{13}$ Francesca Cauchi, "Hegel and Nietzsche on Thought, Freedom, and 'The Labour of the Negative'," in Journal of European Studies, 46:2 (2016), 110. Cauchi's references include those scholars who do not agree with Deleuze. Deleuze's interpretation of Nietzsche may have been influenced by Nietzsche's own reference to dialectic "as a symptom of decadence" in Ecce Homo. And yet in that very same section, Nietzsche not only singles out Socratic dialectic as the object of his criticism, he also boasts about his having "a dialectician's clarity par excellence and... [an ability to] think with cold-blooded lucidity about things." Thus even if Nietzsche were honest about his negative opinion of dialectic, I believe that it was limited to Socratic dialectic. As for Hegelian dialectic, Nietzsche might have been considering himself as an expert of it in that he personally claims to have that "dialectician's clarity par excellence." Friedrich Nietzsche, "Why am I so Wise?" in Ecce Homo: How to Become What you Are, in The Anti-Christ, Ecce Homo, Twilight of the Idols, and Other Writings, ed. by Aaron Ridley and Judith Norman, trans. by Judith Norman (Cambridge: Cambridge University Press, 2005), § 1. Henceforth, Ecce Homo will be referred to as EC.

${ }^{14}$ Cauchi, "Hegel and Nietzsche on Thought, Freedom, and 'The Labour of the Negative'," 110.

${ }^{15}$ Ibid., 111.

${ }^{16}$ The Birth of Tragedy is Nietzsche's very first published book (1872). For further reading, see Friedrich Nietzsche, The Birth of Tragedy and Other Writings, trans. by Raymond Geuss and Ronald Speirs (Cambridge: Cambridge University Press, 1999). Henceforth, The Birth of Tragedy will simply be referred to as BT.
}

(C) 2018 Alexis Deodato S. Itao https://www.kritike.org/journal/issue 22/itao june2018.pdf ISSN 1908-7330 


\section{A CONTINUUM OF TRIPLE DIALECTIC}

between Dionysius and Apollo, the book's central subjects. Nietzsche takes Dionysius like Hegel's thesis, Apollo like its antithesis, and the tragic artist like their synthesis. ${ }^{17}$ Nietzsche himself confesses that $B T$ "smells offensively Hegelian." 18 And I would say that his other writings "smell" Hegelian too. As Richardson observes, Nietzsche's method always involves the reversing of perspectives which "has the dialectical intent of constructing out of the conflict a new and better view." 19 For this reason, Richardson concludes that the Nietzschean method "is more Hegelian, because it's more dialectical." ${ }^{20}$ It starts by positing an inherent contradiction not only between two perspectives but also between two notions, "truths," movements, etc., then continues by seeking their resolution through a "synthesis" of these contradictions. ${ }^{21}$ Thus it would not be correct to label Nietzsche as a pure philosopher of contradiction; he is as much a philosopher of dialectic since he never stops at contradictions but rather always looks for some "synthesis" that could bring them together. ${ }^{22}$

Moreover, if we closely examine Thus Spoke Zarathustra, there are two passages in which Nietzsche implies the necessity of dialectic in the continuous process of self-overcoming and becoming. In the first passage, he says: "I am that which must always overcome itself... I must be struggle and becoming and purpose and the contradiction of purposes." ${ }^{23}$ Then in the second, he declares: "Whatever I may create and however I may love it - soon I must oppose it and my love, thus my will wants it." ${ }^{24}$ In many ways, these passages from TSZ echo Nietzsche's appropriation of Hegel's dialectic. ${ }^{25}$ And such is the Hegelian character of Nietzsche's thinking that Jacob Golomb even

\footnotetext{
${ }^{17}$ See Kaufmann, “Nietzsche's Admiration for Socrates," 475. See also Footnote 50.

${ }^{18}$ Nietzsche, "BT" in $E C, \S 1$.

${ }^{19}$ Richardson, Nietzsche's System, 269. Emphasis by Richardson.

${ }^{20}$ John Richardson, Nietzsche's New Darwinism (Oxford: Oxford University Press, 2004),

${ }^{21} \mathrm{Ibid}$.

22 See Tom Bailey, review of Nietzsche: His Philosophy of Contradictions and the
} 124. Emphasis by Richardson. Contradictions of His Philosophy, by Wolfgang Müller-Lauter, in Journal of Nietzsche Studies, 25 (2003), 95-100.

${ }^{23}$ Friedrich Nietzsche, Thus Spoke Zarathustra, ed. by Adrian Del Caro and Robert Pippin, trans. by Adrian Del Caro (Cambridge: Cambridge University Press, 2006), 89. Henceforth, Thus Spoke Zarathustra will be referred to as TSZ.

${ }^{24}$ Ibid., 90.

${ }^{25}$ See Cauchi, "Hegel and Nietzsche on Thought, Freedom, and 'The Labour of the Negative'," 121-123; Jacob Golomb, "Will to Power: Does It Lead to the 'Coldest of All Cold Monsters'?" in The Oxford Handbook of Nietzsche, ed. by Ken Gemes and John Richardson (Oxford: Oxford University Press, 2013), 526; Richard Lowel Howey, Heidegger and Jaspers on Nietzsche: A Critical Examination of Heidegger's and Jaspers' Interpretation of Nietzsche (The Hague: Martinus Nijhoff, 1973), 160. Howey believes that the dialectic of self-overcoming and becoming in Nietzsche, which is essential in the process of self-creation, "is a profoundly Hegelian idea."

(C) 2018 Alexis Deodato S. Itao

https://www.kritike.org/journal/issue 22/itao june2018.pdf

ISSN 1908-7330

(cc) BY-NC-ND 
goes as far as to say that dialectic is the "clue" to Nietzsche's philosophizing. ${ }^{26}$ There is always something in Nietzsche's method that "is reminiscent of Hegel's dialectic." 27 Jeffrey Jackson aptly calls this Nietzschean dialectic "negative dialectic" because like Hegel's, Nietzsche's involves some form of negation, that is, the loss of cherished perspectives, ideals, concepts, etc. ${ }^{28}$ "But Nietzsche's dialectic, like that of Hegel, makes negation a positive, dynamic power in nature and history," affirms Rose Pfeffer. ${ }^{29}$

Therefore, I contend that in his corpus, Nietzsche employs a dialectic which is akin to Hegel's. It is not a dialectic which, in Deleuze's opinion, is a mere "synthesis of forces." ${ }^{30}$ Nietzsche's is a teleological dialectic like Hegel's. It culminates in liberation, in the freedom of the spirits. As Will Dudley notes, Nietzsche, following Hegel, is "engaged in determining the ontology of freedom, or what it is to be free." 31 This explains why Nietzschean philosophizing is ultimately aimed towards our becoming free spirits. But this does not mean that once we become free spirits, we have already reached the very end of the road. Becoming free spirits entails a continuous dialectic of self-creation, a dialectic that knows "no final conclusion." 32 Nietzsche's, then, is a teleological dialectic because it has a clear direction towards which it aims to arrive - the freedom of the spirits - and not because it leads to the acquisition of any final essence. ${ }^{33}$ And what makes Nietzsche's dialectic even more Hegelian, in my view, is the centrality of Becoming as the constant starting point of dialectic. ${ }^{34}$ Nietzsche's dialectic, unfortunately, has been

${ }^{26}$ Golomb, "Will to Power: Does It Lead to the 'Coldest of All Cold Monsters'?" 526.

${ }_{27}$ Walter A. Kaufmann, Nietzsche: Philosopher, Psychologist, Antichrist, $4^{\text {th }}$ ed. (Princeton: Princeton University Press, 2013), 80. Even Jacques Derrida, the noted philosopher of deconstruction, who is said to agree with Deleuze on the irreconcilable gap between Nietzsche and Hegel, could not help but admit: "It can be shown easily. There is a dialectic in Nietzsche, a Hegelianism." Jacques Derrida, L'oreille de l'autre, 82, quoted in John Llewelyn, Margins of Religion: Between Kierkegaard and Derrida (Bloomington: Indiana University Press, 2009), 229.

${ }^{28}$ Jeffrey M. Jackson, Suffered and Social Histories: Genealogy and Convalescence (New York: Palgrave Macmillan, 2017), 5, 51.

${ }^{29}$ Rose Pfeffer, Nietzsche: Disciple of Dionysius (Cranbury: Associated University Presses, 1972), 237.

30 Ronald Bogue, Deleuze and Guattari (London: Routledge, 1991), 30. For a good Deleuzian reading of Nietzsche, I recommend Paolo A. Bolaños, On Affirmation and Becoming: A Deleuzian Introduction to Nietzsche's Ethics and Ontology (Newcastle upon Tyne: Cambridge Scholars Publishing, 2014).

31 Will Dudley, Hegel, Nietzsche, and Philosophy: Thinking Freedom (Cambridge: Cambridge University Press, 2002), 238.

${ }^{32}$ Golomb, "Will to Power: Does It Lead to the 'Coldest of All Cold Monsters'?" 537.

33 The teleological character of Nietzsche's dialectic can never be construed to mean that he is leaning towards essentialism. In Nietzsche, the never-ending dialectic of self-creation leaves no room for anyone to get hold of any unchanging essence.

${ }^{34}$ See Forster, "Hegel's Dialectical Method," in Cambridge Companion to Hegel, 133.

(C) 2018 Alexis Deodato S. Itao

https://www.kritike.org/journal/issue 22/itao june2018.pdf

ISSN 1908-7330

(cc) BY-NC-ND 


\section{A CONTINUUM OF TRIPLE DIALECTIC}

mostly forgotten, in large part due to the influence of Deleuze. There is therefore the need to recover it.

In this paper, I intend to show that Nietzsche is consistent in employing not just one, but a continuum of triple dialectic throughout his writings. This is especially evident in his philosophy of the incarnation of the free spirits, a recurring theme in his works. In addition, I argue that to become a free spirit, one must constantly apply the dialectics of (1) criticality and openness, (2) unlearning and relearning, and (3) overcoming and becoming. ${ }^{35}$ As an attempt to come up with a comprehensive synthesis of the conditions that would favor the incarnation of the free spirits, I will further show that these dialectics permeate Nietzsche's works starting from the early period up to the final period of his literary productivity.

\section{The Incarnation of the Free Spirits in the Early Period}

Nietzsche's writings have been traditionally categorized into "three distinct periods" consisting of an early (1872-76), middle (1878-85), and late or final (1886-88) periods. ${ }^{36}$ This categorization accordingly reflects the development of Nietzsche's literary concerns: from being relatively philological at the start, to increasingly and ultimately being philosophical. ${ }^{37}$ Since the middle period of his writing career, Nietzsche began to repetitively speak about the "free spirit" (Freigeist). In fact, his books during this periodHuman All Too Human, Daybreak, and Gay Science-comprised of what he himself called "the free spirit trilogy." 38

The "free spirits" refer to Nietzsche's higher type of human beings. ${ }^{39}$ He labeled them "free" precisely because they are those few who are no

${ }^{35}$ I admit that Nietzsche never explicitly described the overarching themes of his writings in terms of the following dialectical categories: criticality and openness, unlearning and relearning, and becoming and overcoming. All the same, I will endeavor to show in this paper that these dialectical categories are implied in his oeuvre by citing passages from Nietzsche himself as well as from selected secondary sources.

${ }^{36}$ Keith Ansell Pearson, "Friedrich Nietzsche: An Introduction to his Thought, Life, and Work," in A Companion to Nietzsche, ed. by Keith Ansell Pearson (Victoria, Australia: Blackwell Publishing, 2006), 11.

${ }^{37}$ Nietzsche started his career not as a philosopher but as a professor of classical philology at the University of Basle, becoming the youngest, at age 24 , to hold such position in 1869. He would eventually be forced to resign in 1879 owing to constant health issues.

${ }^{38}$ Pearson, "Friedrich Nietzsche: An Introduction to his Thought, Life, and Work," 11. Nietzsche did not actually use the word "trilogy," but at the opening page of Gay Science, he indicated that Human All Too Human, Daybreak, and Gay Science all belong to the same series, "whose common goal it is to erect a new image and ideal of the free spirit" (emphasis by Nietzsche). For details, see Friedrich Nietzsche, The Gay Science, trans. by Walter Kaufmann (New York: Vintage Books, 1974). Henceforth, Gay Science will be referred to as GS.

${ }^{39}$ Nietzsche would often speak about the free spirits in contrast to the "fettered spirits" whom he classified as lower human beings. See Friedrich Nietzsche, Human All Too Human: A

(C) 2018 Alexis Deodato S. Itao

https://www.kritike.org/journal/issue 22/itao june2018.pdf

ISSN 1908-7330

(c) BY-NC-ND 
longer chained by the fetters of history, culture, philosophy, science, morality, and religion. ${ }^{40}$ The highest - or better yet, the "more perfected version" 41 - of these free spirits is the "overman" (Übermensch). ${ }^{42}$ However, Nietzsche reveals that they do not yet exist nor did they exist before. ${ }^{43}$ For now, they are ghosts devoid of flesh and lacking physicality. ${ }^{44}$ Despite this, Nietzsche hopes that they may appear in the future even if at present they remain a dream, an aspiration. ${ }^{45}$ In other words, the incarnation of the free spirits is always an open possibility. And yet, how will it come about? What will bring about the concrete existence of the free spirits in the future?

Although it was only during the middle period of his writing career that Nietzsche fully developed and began to specifically talk about the free spirits, he had already hinted about them in the early period. ${ }^{46}$ In $B T$, for example, the free spirits are described as those who are no longer constrained by any form of Socratism ${ }^{47}$ that has plagued modern culture and society for millennia. Socratism for Nietzsche is "a sign of decline, of exhaustion, of sickness, of the anarchic dissolution of the instincts" because it implies rigidity and dogmatism. ${ }^{48}$ The various forms of Socratisms include: aesthetic Socratism (what is beautiful or pleasurable is what is reasonable); scientific Socratism (only what is empirically observable is knowable); logical Socratism (only what can be proven as true is valid); and ethical Socratism

Book for Free Spirits, trans. by R. J. Hollingdale (Cambridge: Cambridge University Press, 1986), passim. Henceforth, Human All Too Human will be referred to as $\mathrm{HH}$.

${ }^{40}$ See ibid., passim. Nietzsche also states that the term "free spirit" refers plainly to "a spirit that has become free, that has taken hold of itself again" (emphasis by Nietzsche). See Nietzsche, "HH," in $E C, \S 1$.

41 Sheridan Hough, Nietzsche's Noontide Friend: The Self as Metaphoric Double (Pennsylvania: The Pennsylvania State University Press, 1997), 88.

42 Walter Kaufmann was the first to translate Übermensch as overman to emphasize that such a human being is someone who is already over himself, that is, he has already overcome himself (his human nature and tendencies). I am adopting this translation in this paper because it is closely connected to our objective of presenting the dialectic of overcoming and becoming as one of the pathways towards his (overman) incarnation. For details on the explanation of overman as the more appropriate translation for Übermensch, see Walter Kaufmann, editor's note to Friedrich Nietzsche, The Portable Nietzsche, ed. and trans. by Walter A. Kaufmann (London: Penguin Books, 1954), 115-116.

${ }^{43}$ See Nietzsche, Preface to $H H$, vol. $1, \S 2$.

${ }^{44}$ See Nietzsche, TSZ, 44.

${ }^{45}$ See ibid.

${ }^{46}$ Henceforth, the three periods of Nietzsche's writing career will be simply referred to as the early period, the middle period, and the late period.

${ }^{47}$ In BT, Nietzsche criticizes German culture and society for its tendency to be rigid, dogmatic, and autocratic. He calls this tendency on the whole as Socratism, after Socrates whom he blames for pioneering Western aesthetics, logic, science, ethics, etc. See BT, passim.

${ }^{48}$ Nietzsche, "An Attempt at Self-Criticism," in BT, § 1 .

(C) 2018 Alexis Deodato S. Itao

https://www.kritike.org/journal/issue 22/itao june2018.pdf

ISSN 1908-7330 


\section{A CONTINUUM OF TRIPLE DIALECTIC}

(what is moral is what is within the accepted norms). ${ }^{49}$ Metaphorically, the free spirits are typified by the artist who embodies the "Dionysiac-Apolline genius." 50 Such an artist ideally represents the free spirit: a liberated person who is not chained by Socratism.

After $B T$, Nietzsche composed two other writings where he also hints about the free spirits. In the posthumously published essay "On Truth and Lying in a Non-Moral Sense," Nietzsche alludes to the free spirit as "the man of intuition" who is not conditioned by the clasps of concepts and abstractions. ${ }^{51}$ Meanwhile, in the Unfashionable Observations, the free spirits refer to those "unfashionable" individuals (Unzeitgemassheit) who have succeeded in untangling themselves from the reins of the "fashionable," that is, the present cultural trends and norms that dictate how people ought to live and conduct themselves. ${ }^{52}$ So albeit not yet expounded as a concept, discernible traces of the free spirits were already in place in the early period. These spirits may one day appear, Nietzsche hopes; but for someone to become an authentic free spirit, he must firstly be critical, questioning everything that has been established by culture, society, religion, tradition, etc. This is because criticality is an attribute of a genuine free spirit. ${ }^{53}$ Even so, being critical is not enough; it is equally important to be open, willing to embrace new truths and fresh ideas. ${ }^{54}$ Therefore, to become a truly free spirit, a person must constantly employ a dialectic of criticality and openness.

${ }^{49}$ For aesthetic Socraticsm see Nietzsche, BT, § 12; for logical Socratism, see ibid., § 13; for scientific Socratism, see ibid., § 19; and for ethical Socratism, see "An Attempt to SelfCriticism," in $B T, \S 1$.

${ }^{50}$ Nietzsche, $B T, \S 5$. Nietzsche observes that the tragic plays of ancient Greeks combine both Apolline (after Apollo, the god of music, poetry, moderation, and harmony) and Dionysiac (after Dionysius, the god of wine, ritual madness, intoxication, wild frenzy, and pleasure) elements. For Nietzsche, the good life is one that closely resembles a pre-Socratic ancient Greek tragedy. It is one that always makes room for a healthy amount of balance between artistic creativity (Apolline) and instinctive impulse (Dionysiac).

${ }^{51}$ Nietzsche, "On Truth and Lying in a Non-Moral Sense," § 2 in BT, 152. Concepts and abstractions are products of reason. But for Nietzsche, reason does not and cannot tell us the truth. So, anything that comes from reason must be subjected to critical scrutiny. Henceforth, "On Truth and Lying in a Non-Moral Sense" will be referred to as TL.

${ }^{52}$ Friedrich Nietzsche, Unfashionable Observations, trans. by Richard T. Gray (Stanford, California: Stanford University Press, 1995), 179, 194. For further information, see also Gray, translator's afterword to Nietzsche, ibid., 395-413. Henceforth, Unfashionable Observations will be referred to as $U O$.

${ }^{53}$ Criticality for Nietzsche is closely linked to truthfulness, to a new way of practicing honesty (Redlichkeit) that is a central trait of every free spirit. For details, see Katrina Mitcheson, Nietzsche, Truth and Transformation (London: Palgrave Macmillan, 2013), 140-150.

${ }^{54}$ See Nietzsche, UO, 144, 249.

(C) 2018 Alexis Deodato S. Itao

https://www.kritike.org/journal/issue 22/itao june2018.pdf

ISSN 1908-7330

(c) $\mathrm{BY}-\mathrm{NC}-\mathrm{ND}$ 


\section{A. Between Criticality and Openness: The First Dialectic in the Early Period}

When $B T$ first came out of publication in 1872, it did not receive a favorable reception. ${ }^{55}$ The opus, anyway, was overly critical of German culture and society. But that was really Nietzsche's intention at the outset: to criticize. Because for him, that's the only way to go ahead; that is to say, only by being critical of Socratism in all its disguises "might one hope for a rebirth of tragedy" 56 - a rebirth which simultaneously denotes a new encounter with the free spirits. Without being critical, the spirit will remain unfree, confined within the rigid sphere of Socratic rationalism.

For Nietzsche, to be critical does not simply mean to be fault-finding. More than this, Nietzschean criticality is one which necessitates pessimism, ${ }^{57}$ skepticism, ${ }^{58}$ and nihilism. ${ }^{59} \mathrm{TL}$, for instance, is a highly critical essay which abounds in pessimistic, skeptic, and nihilistic pronouncements. More like an extension to $B T$, it continues its barrage of tirades against Socratism that had pervaded German culture and society in Nietzsche's time. And that was so that there will finally be liberation: the freedom of the spirits from the hands of the "daemon called Socrates." 60

Nietzsche resumes his usual diatribes in $U O$, but this time it is now against what we might consider the offspring of Socratism: philistinism. The "philistines" were the German cultural elite who Nietzsche derides on

${ }_{55}$ BT was originally titled The Birth of Tragedy Out of the Spirit of Music. In 1886, Nietzsche released the book anew, this time revising its title, making it The Birth of Tragedy, Or: Hellenism and Pessimism. He also added a preface with the title "An Attempt at Self-Criticism."

${ }^{56}$ Nietzsche, $B T, \S 17$.

${ }^{57}$ Nietzsche's pessimism is heavily influenced by Arthur Schopenhauer (1778-1860) who espoused a generally negative view of life and the world. But unlike Schopenhauer's, Nietzsche's "tragic" view of life is not hopeless. It is precisely in tragedy where we can better understand our life and the world. For further reading on Nietzsche's pessimism, see Roger Hollinrake, Nietzsche, Wagner, and the Philosophy of Pessimism (New York: Routledge, 2010).

${ }^{58}$ In the late period, Nietzsche would make a more explicit connection between criticality and skepticism, saying that a philosopher, as a free spirit, is better off if he were a critic and a skeptic at the same time. For details, see Friedrich Nietzsche, Beyond Good and Evil, ed. by Rolf-Peter Horstmann and Judith Norman, trans. by Judith Norman (New York: Cambridge University Press, 2002), 106. Henceforth, Beyond Good and Evil will be referred to as BGE.

${ }^{59}$ There are two ways of looking at nihilism in Nietzsche's context: first, as an approach to, and second, as a problem in, modern culture. With regard to the first, Nietzsche's criticism of modernity may be classified as a form of nihilism in that for him, nothing (nihil) in it-especially its metaphysical and religious claims - can be held as certain and true. With regard to the second, Nietzsche himself accuses modern culture to be suffering from nihilism. "Nihilism is at our door," he says in The Will to Power. And that's because "the highest values are losing their value" (emphasis by Nietzsche). For details, see Friedrich Nietzsche, The Will to Power, ed. by Oscar Levy and trans. by Anthony M. Ludovici (New York: Gordon Press, 1974), 5, 8.

${ }^{60}$ Nietzsche, $B T$, § 12. Emphasis by Nietzsche.

(C) 2018 Alexis Deodato S. Itao

https://www.kritike.org/journal/issue 22/itao june2018.pdf

ISSN 1908-7330

(cc) BY-NC-ND 


\section{A CONTINUUM OF TRIPLE DIALECTIC}

account of their arrogance, self-conceit, and autocratic tendency. Nietzsche, moreover, makes it clear that he doesn't want to have anything to do with this "despicable philistinism." 61 This cultural pathology discourages people from pursuing "wild experimentation" and from following their artistic "creative drive," in effect preventing the free spirits from coming to life. ${ }^{62}$

As we have looked into Nietzsche's works in the early period, it is evident that criticality is ever necessary if the free spirits were to be given the chance to live. Be that as it may, Nietzsche-in spite of his tendency to be extremely critical-recognizes that criticality cannot be absolute. It still needs to be balanced by a hefty dose of openness. ${ }^{63} \mathrm{I}$ also believe that if a free spirit were purely critical and closed-minded, he would not be truly free; he would be a prisoner of his own closed-mindedness and intellectual myopia. Instead, Nietzsche encourages openness to go along with criticality. His stubborn insistence on perspectivism strongly supports this claim. Perspectivism ${ }^{64}$ connotes that I cannot insist my views on another inasmuch as his or her views may have some merits and truth. In the same way, the other cannot insist his or her views on me as well. Truth can always be viewed from different angles - or, to be more precise, from different perspectives. ${ }^{65} \mathrm{Hence}$, much as I want to be critical, I should just the same be constantly open. We can thus suppose that for Nietzsche, the free spirits are not solely critical but also open. Though they are pessimists (critical thinkers), they are also a bunch of optimists: people who have hope about the future.

In many ways, Nietzsche exemplifies the free spirits. Towards the end of $B T$, for example, Nietzsche actually expresses hope that the German spirit will someday free itself from the ropes of Socratism which is currently

${ }^{61}$ Nietzsche, UO, 10-11, 44.

62 Ibid., 14.

${ }^{63}$ In $U O$, Nietzsche leaves a number of hints about the value and importance of openness. In one of these, he says that it would make him happy if educated people would also know how "[t]o accept everything objectively, get irate about nothing, love nothing, [and] comprehend everything." In my interpretation, Nietzsche here is implying that it's not enough to be educated (critical); it's also necessary to know how to accept everything, that is to say, to be open. In the later part of $U O$, Nietzsche likewise speaks of the need for "cultivated people ... [to be] ready to receive hints and suggestions, and [welcome] the smallest real truth." I still interpret this passage to imply that being cultivated (hence, having a critical mind) should be balanced by being open (being ready to receive hints and suggestions). For details, see Nietzsche, UO, 144, 249.

${ }^{64}$ At first glance, Nietzsche's concept of perspectivism sounds no different from relativism. However, the two are different. As one Nietzschean scholar succinctly explains, "Perspectivism ... is not equivalent to relativism .... Perspectivism does not result in the relativism that holds that any view is as good as any other; it holds that one's own views are the best for oneself without implying that they need to be good for anyone else." For details, see Alexander Nehamas, Nietzsche: Life as Literature (Cambridge, Massachusetts: Harvard University Press, 1985), 49, 72.

${ }^{65}$ Nietzsche, Preface to $H H$, vol. $1, \S 6$.

(C) 2018 Alexis Deodato S. Itao

https://www.kritike.org/journal/issue 22/itao june2018.pdf

ISSN 1908-7330

(cc) BY-NC-ND 
tying it. He said: "One day it will find itself awake, with all the morning freshness that comes from a vast sleep; then it will slay dragons, [and] destroy the treacherous dwarfs ..." 66 The free spirits are neither total skeptics. In $T L$, we get a glimpse of how, though they continue to despise the dictates of reason-the residues of Socratism-the free spirits are ever open to the insinuations of intuition. ${ }^{67}$ The free spirits cannot be categorized as pure nihilists too. Though Nietzsche proclaimed himself "as the first complete or perfect nihilist," ${ }^{68}$ this is more of a hyperbole than fact. The nihilism of the free spirits certainly does not exclude the possibility that there could still be some truths out there. Nihilism for Nietzsche may denote "a pathological loss of trust in the world," 69 but in $U O$, he unmistakably suggests that no nihilist can totally negate the "experience [of] true satisfactions" brought about by love. ${ }^{70}$ This goes to show that the free spirits, while maintaining a nihilistic (critical) outlook about the world, remain open to the truth of love, to that "something most marvelous and most sublime." 71

As we have seen, the interplay of criticality and openness dominates Nietzsche's works in the early period. And the free spirits, even if not yet fully conceptualized at this point, clearly cannot exist sans appropriating the dialectic of criticality and openness. They must, by necessity, be both critical and open. However, the dialectic of criticality and openness alone does not suffice in bringing about the incarnation of the free spirits. There is another tier of dialectic that needs to be taken up: that between unlearning and relearning.

\section{B. Between Unlearning and Relearning: The Second Dialectic in the Early Period}

In Nietzsche's view, the problem with German culture during his time is that Socratism and philistinism have been deeply ingrained in it. Their perennial presence has resulted into the suppression of the free spirits. But once this problem is recognized through the lens of criticality, the next logical step is to unlearn it. Otherwise, the problem remains: Socratism and philistinism persist like an incurable disease that has no more hope of remedy; the existence of the free spirits continues to be an elusive dream. But

\footnotetext{
${ }^{66}$ Nietzsche, $B T, \S 24$.

${ }^{67}$ See Nietzsche, $T L, \S 2$.

${ }^{68}$ Pearson, "Friedrich Nietzsche: An Introduction to his Thought, Life, and Work," 17.

${ }^{69}$ Andreas Urs Sommer, "Nihilism and Skepticism in Nietzsche," in A Companion to Nietzsche, 250

${ }^{70}$ Nietzsche, $U O, 328$.

${ }^{71} \mathrm{Ibid}$. For my explication of Nietzsche's hints on the value and importance of openness in the early period, refer to Footnote 63.
}

(C) 2018 Alexis Deodato S. Itao https://www.kritike.org/journal/issue 22/itao june2018.pdf ISSN 1908-7330 


\section{A CONTINUUM OF TRIPLE DIALECTIC}

what does this unlearning consist of? How should it be done? In BT, Nietzsche notes that the process of unlearning begins with a culture's rejection "of those foreign elements which have been forcibly grafted on to it." 72 This is not an easy task; it calls "for a hard fight." 73 It requires a "zealous ambition" similar to that of "all our great artists and poets." 74 As such, those who are faint-hearted cannot accomplish this task. In $T L$, Nietzsche identifies the receptacle of the aforesaid cultural pathologies: the intellect. For a long time, the intellect has been the slave of Socratism and philistinism. If there should be unlearning, it must mean one thing: the intellect casting off its "mark of servitude," 75 setting aside the authority of reason, and embracing the new supremacy of intuition. Only when the manacles of the slavery of Socratism and philistinism are discarded will it be possible for the free spirits to be incarnated.

Nietzsche gets bolder but more realistic in UO. He asserts that our only hope of successfully carrying out the arduous task of unlearning is "to replace the fundamental principles of our present education system ... with a new fundamental principle." 76 This may entail "a possible upheaval in our educational system," 77 Nietzsche admits, but it is so much better than settling as an ignorant slave of Socratism and philistinism by refusing to unlearn. All the same, unlearning for Nietzsche remains one side of the coin. On the other side, there is relearning. Every unlearning has to be accompanied by relearning. The two must go together; they must be engaged in a dialectic. Unlearning cannot be the end of the process that seeks to enflesh the free spirits because if it were so, we would end up with dull and hopeless spirits, forever closed to the possibility of learning new things. Thus, there should always be relearning.

$B T$ is an invitation to relearn from the ancient Greeks how life ought to be lived by drawing essential lessons from how they originally staged tragedy prior to the advent of Socrates and/or Euripides. After all, they were the epitome of the free spirits - in a metaphorical sense at least. TL similarly bids us to relearn the subtle voices of our intuition which are often silenced by the cacophonies of various noises emanating from reason. For it is through continual relearning that one gets on the track of becoming a free spirit. No longer bound by the order of rationalism, the free spirits are those who have relearned how to follow their intuition which has been shelved in favor of reason. In $U O$, Nietzsche categorically states that "relearning [is]

\footnotetext{
72 Nietzsche, $B T$, § 23 .

${ }^{73}$ Ibid., § 20.

74 Ibid., § 23.

${ }^{75}$ Nietzsche, $T L, \S 2$.

${ }^{76}$ Nietzsche, UO, 232.

77 Ibid., 234.
}

(C) 2018 Alexis Deodato S. Itao

https://www.kritike.org/journal/issue 22/itao june2018.pdf

ISSN 1908-7330

(c) BY-NC-ND 
necessary." 78 This can be done through education. But it must be the kind of education whose fundamental principles have already been overhauled for it is imperative to "possess that necessary formation." 79 Nietzsche further reveals that "education is liberation, removal of all weeds, rubble, and vermin that seek to harm the plant's delicate shoots." 80 There may be other ways to become a free spirit, he acknowledges, but no other way is better than education. ${ }^{81}$

In the process of giving life the free spirit, unlearning and relearning must continually interact in a dialectical relationship. One cannot stand without the other. This fluid equilibrium between the two is what characterizes the free spirits as they are not tied to a particular extreme. They go about freely, unlearning and relearning as they journey on in life-at least, that's how the tragic artists were in ancient Greece; and that's how the free spirits will hopefully be in the unknown future when they will have been finally embodied. But again, completing the incarnation of the free spirits requires yet another tier of dialectic. Aside from the two dialectics we already mentioned-that between criticality and openness, and that between unlearning and relearning-there is still the dialectic of overcoming and becoming.

\section{Between Overcoming and Becoming: The Third Dialectic in the Early Period}

The notion of overcoming is a theme that Nietzsche often speaks in his writings, even in the early period. In $B T$, he specifically identifies what must be overcome: all forms of Socratic tendency, the tendency "to murder art" and repress the creativity of artists. ${ }^{82} T L$ names a related tendency: that of depending on reason and on our inherited notion of what is moral or nonmoral. Likewise, UO presents another common tendency: that of giving more preference to the "fashionable" without much criticality. For Nietzsche, all these tendencies must be overcome. They are what hinder the incarnation of the free spirits. Once the task of overcoming is done, however, the correlative task of becoming must be pursued. But what should one become? From Nietzsche's point of view, it would be later on-in the middle period, that is-when he would have a much clearer grasp about what the goal of every

78 Ibid., 226.

${ }^{79}$ Ibid., 283.

${ }^{80} \mathrm{Ibid}$., 175.

${ }^{81}$ Ibid. For further reading on Nietzsche's educational philosophy, see Friedrich Nietzsche, Anti-Education: On the Future of Our Educational Institutions, trans. by Damion Searls, ed. by Paul Reitter and Chad Wellmon (New York: The New York Review of Books, 2016).

82 Nietzsche, $B T$, §17.

(C) 2018 Alexis Deodato S. Itao https://www.kritike.org/journal/issue 22/itao june2018.pdf ISSN 1908-7330 


\section{A CONTINUUM OF TRIPLE DIALECTIC}

becoming should be. Needless to say, from our point of view, the answer is obvious: one should become a free spirit - a person who has finally liberated himself from Socratism, philistinism, etc. through an incessant exercise of the triple dialectic of criticality and openness, unlearning and relearning, and overcoming and becoming.

\section{The Incarnation of the Free Spirits in the Middle Period}

According to Paolo D'Iorio, it was "in the winter of 1876" in Sorrento when Nietzsche began formulating his "philosophy of the free spirits." 83 Nietzsche's early works may have already hinted about them, but since the free spirits did not yet then mature as a concept, Nietzsche could not provide further details and elaborate on them. From the middle to the late period, the free spirits have become a recurring idea, nay ideal. Not unlike in the early period, the free spirits are still essentially those who have liberated themselves from all types of bondage like cultural impositions, religious dogmatisms, and intellectualism of all kinds grounded on traditional metaphysics, epistemology, science, etc. As an ideal, Nietzsche was honest enough to confess that the free spirits have yet to exist. ${ }^{84}$ In any case, their incarnation requires the same dynamics: a continuum of triple dialectic which we just expounded earlier.

\section{A. Between Criticality and Openness: The First Dialectic in the Middle Period}

In his introduction to $\mathrm{HH}$, Richard Schacht observes that in this book, "nothing is beyond criticism" for Nietzsche; everything must be "subjected to critical scrutiny," to "a strong suspicion." ${ }^{85}$ But there is nothing surprising in this, especially if we take our cue from the book's subtitle: A Book for Free Spirits. For Nietzsche, one of the outstanding features of the free spirits is their being critical: they mistrust the data supplied by the intellect; they question the ability of language to capture the essence of reality and to express truths; they doubt the authority of science, religion, and philosophy. Nietzsche relates: "He is called a free spirit who thinks differently from what, on the basis of his origin, environment, his class and profession, or on the basis of the dominant views of the age, would have been expected of him. He is the exception; the fettered spirits are the rule." 86 The free spirits, therefore, are

\footnotetext{
${ }^{83}$ Richard D'Iorio, Nietzsche's Journey to Sorrento: Genesis of the Philosophy of the Free Spirits, trans. by Sylvia Mae Gorelick (Chicago: University of Chicago Press, 2016), 68.

${ }^{84}$ Nietzsche, Preface to $H H$, vol. $1, \S 2$.

${ }^{85}$ Richard Schacht, Introduction to Nietzsche, $H H, x v$.

${ }^{86}$ Nietzsche, "Tokens of Higher and Lower Culture," in HH, vol. 1, § 225.
} 
those who think out of the box. They are free precisely because they are not conditioned by anything around them.

The problem of modern culture, Nietzsche avers, is rooted in its blind attachment to inherited concepts, metaphysical claims from past philosophers, and rigid dogmatism of religious institutions. But these are precisely what's enslaving it and holding captive the free spirits. Instead, the free spirits are liberated individuals since they have been emancipated from the idiosyncrasies of culture and tradition. They are ever critical of everything that has been institutionalized. However, criticality is not the ultimate attitude for Nietzsche. He values openness just as much. A free spirit does not stop at criticality but goes beyond it by being open to "little unpretentious truths" 87 - that is, those "unimpeachable truths" 88 that have successfully passed the test of rigorous suspicion and intense skepticism.

Let us briefly go over to two other books in this period: Daybreak and GS. In Daybreak, Nietzsche counsels that it is better to always be suspicious and not "to admit a belief merely because it is a custom." 89 Still, this critical attitude alone is not enough so we will become liberated souls. Openness to new experiences and even to new beliefs and customs is just as important. With regard to GS, this is what completes the free spirit trilogy. It culminates what Paul Franco calls a "tremendous development" of Nietzsche's thoughts in the middle period, a development capped by his "adoption of scientific skepticism," marking the maturation of his philosophical position. ${ }^{90}$ Assuming a scientist-skeptic persona, Nietzsche in GS attacks religious truths, especially the idea of faith. He wants to convey that a free spirit is one who is not its hostage. He is a critical spirit, the kind of "spirit [that] would take leave of all faith and every wish for certainty." "91 "Such a spirit," Nietzsche continues, "would be the free spirit par excellence." 92 Yet even with its heightened criticality towards established norms and truths, Nietzsche was the first to admit that GS is a book marked by gay or merry openness: to the future, upcoming adventures, new prospects, fresh possibilities and goals. ${ }^{93}$ Moreover, as one of the books for free spirits, GS's characteristic openness indicates that the free spirits are not closed to the idea that there are

\footnotetext{
${ }^{87}$ Ibid., "Of the First and Last Things," §3.

${ }^{88} \mathrm{Ibid} . \S 22$.

89 Friedrich Nietzsche, Daybreak: Thoughts on the Prejudices of Morality, ed. by Maudemarie Clark and Brian Leiter, trans. by R.J. Hollingdale (Cambridge: Cambridge University Press, 1997), 59. Henceforth, Daybreak will be simply referred to as DB.

90 Paul Franco, Nietzsche's Enlightenment: Free-Spirit Trilogy of the Middle Period (Chicago: University of Chicago Press, 2011), xiv.

${ }^{91}$ Nietzsche, GS, § 347.

${ }_{92}$ I bid. Emphasis by Nietzsche.

${ }^{93}$ Nietzsche, Preface for the Second Edition to ibid., $\S 1$.
}

(C) 2018 Alexis Deodato S. Itao https://www.kritike.org/journal/issue 22/itao june2018.pdf ISSN 1908-7330 


\section{A CONTINUUM OF TRIPLE DIALECTIC}

still truths out there that are worth believing in. So, while they remain critical, the free spirits are ever open.

\section{B. Between Unlearning and Relearning: The Second Dialectic in the Middle Period}

Criticality for Nietzsche always goes along with a corresponding action: unlearning. It is not by chance that his free spirit trilogy all point to the same things that must be unlearned: the so-called "truths" of science, religion, history, philosophy, etc. There's no need to go into detail into every one of these. Nietzsche is admirably consistent when it comes to the end-goal of most of his works: the abolition of traditions, customs, beliefs, and so forth. ${ }^{94}$ All these delay, if not really obstruct, the incarnation of the free spirits.

But just as criticality must be paired with openness, unlearning must also be paired with relearning. The things that have been relegated by science, religion, philosophy, etc. are what must be relearned. This is why there's a need for an "artistic education of the public," 95 because our artistic impulses are among those that science, religion, etc. have caused us to lose. Furthermore, Nietzsche calls for a "re-education of the human race." 96 There must be a lot of things that we need to relearn. Nietzsche himself did not fail to express his own desire to keep on relearning "in order to see as beautiful what is necessary in things; then I shall be one of those who make things beautiful." ${ }^{97}$ But what guarantees re-education? How do we know that one has been successfully re-educated? ${ }^{98}$

Here Nietzsche introduces the concept of "intellectual conscience" ${ }^{99}$-the "conscience behind your "conscience." 100 It's not

94 Although Nietzsche wants everything that has been institutionalized to be eradicated, it should be kept in mind that Nietzsche is not an absolute nihilist. He himself advocates for the establishment of a new ethics, new philosophy, new education, etc., albeit with a caveat that none of these should become absolute. Otherwise, they will have to be eradicated like their predecessors.

${ }^{95}$ Nietzsche, "From the Souls of Artists and Writers," in $H H$, vol. 1, § 167. Emphasis by Nietzsche.

${ }^{96}$ Nietzsche, $D B, 13$. Emphasis by Nietzsche.

${ }^{97}$ Nietzsche, GS, § 276.

${ }_{98}$ Nietzsche is a staunch critic of educational institutions. Even so, he recognizes the value of education. For him, since education has been "corrupted" by the influence of tradition, religion, science, etc. then there has to be re-education. He is very much aware, though, that any form of re-education could still turn into a rigid, scientific, religious, or traditional process. When that happens, then a new process of unlearning will be required so that a new process of relearning (re-education) may start. In Nietzsche, nothing ever becomes permanent. This is why I contend that the dialectic of unlearning and relearning is very much implied in Nietzsche's thinking.

${ }^{99}$ Nietzsche, GS, § 2.

${ }^{100}$ Ibid., $\S 335$.

(C) 2018 Alexis Deodato S. Itao

https://www.kritike.org/journal/issue 22/itao june2018.pdf

ISSN 1908-7330

(c) BY-NC-ND 
conscience in the Scholastic sense that lets you distinguish right from wrong. Rather, it is conscience in the Nietzschean sense: that is, a critical acuity that lets you sharply tell between what is dictated by the norm and what is not. Thus, if there is any indication that one has been properly "re-educated," it is when he begins to exercise his intellectual conscience. The free spirits are men of intellectual conscience, but it's not because they are now disposed to obey the dictates of reason; it's more because the way they now approach things is no longer based on the standards fixed by traditions and customs but on their independent thinking. In short, having intellectual conscience means thinking big. As Nietzsche sarcastically remarks in TSZ, "Indeed, better to do evil than to think small!" 101

\section{Between Overcoming and Becoming: The Third Dialectic in the Middle Period}

Towards the end of the middle period, Nietzsche arrived at a more mature conception of the free spirits. They are not simply those who have managed to unlock themselves from every tradition and institution. They are now the "overman" (Übermensch) - the free spirit in his finest form. ${ }^{102}$ One major factor is responsible for this "upgrading," and that is constant overcoming. The concept of overcoming (Überwindung) is significant in the philosophy of Nietzsche, appearing recurrently in all his writings. It pertains to our having to conquer and transform ourselves in order to become unchained, to become free spirits. ${ }^{103}$

In TSZ, instead of the usual discourse on the free spirits, Nietzsche kept on pointing toward the Übermensch. It could be because he probably thought that if we should become free spirits, we better be the higher type than the ordinary one. Nietzsche himself disclosed that this was the mission of Zarathustra: to teach about overman, or more specifically, about how to become an overman. ${ }^{104}$ Right in the opening pages of TSZ, Nietzsche laid down the most basic principle in order to become an overman: overcoming. Zarathustra declared, "Human being is something that must be overcome. What have you done to overcome him?" 105 In the same book, Nietzsche shared that overcoming is a never-ending process, thereby implying that we too should be in a continuous state of becoming. The three metamorphoses of

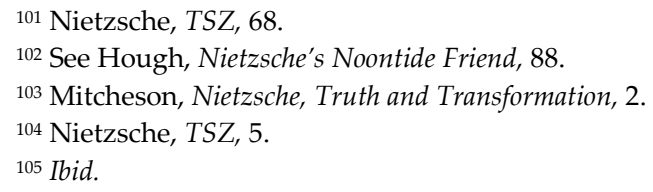

(C) 2018 Alexis Deodato S. Itao 


\section{A CONTINUUM OF TRIPLE DIALECTIC}

the spirit ${ }^{106}$ represent the number of possibilities that is constantly open before us. Whenever we become a camel, we overcome it by becoming a lion; whenever we become a lion, we overcome it by becoming a child; and whenever we become a child, we overcome it by again becoming a camel, and so forth.

One of the biggest hurdles in becoming an overman is what Nietzsche calls eternal recurrence. ${ }^{107}$ It is a notion that Nietzsche introduces in the middle period as a sort of existential challenge to every individual, a challenge to respond to very crucial "what if" questions, like: What if everything-your life, relationships, job, physical looks, abilities, etc.-is actually eternally recurring? What if the way things are happening right now will happen again and again in exactly the same way for all eternity? How will you live your life? ${ }^{108}$ The implications are enormous. The mere thought of it deeply bothered Zarathustra. In fact, he was in coma for seven days, unable to bear the bleak prospect, this "most abysmal thought" of having to eternally live the same life in exactly the same way. ${ }^{109}$ Zarathustra likened the idea of eternal recurrence to a crawling monster that gets into his throat and chokes him. But Zarathustra was able to bite its head off and spit it away. ${ }^{110}$ This, for Nietzsche, is how one becomes an overman: you don't live your life in despair just because things are recurring eternally; rather, you affirm your identity, biting off the head of the crawling monster that gets into your throat and chokes you. Only such an affirmation can allow you to overcome the monotony of ordinary existence. But to do so entails using one's will power, or in Nietzschean language, the will to power, ${ }^{111}$ so that you can be in full

106 The three metamorphoses of the spirit are the three continuous cycle of becoming that are open to the spirit: that of becoming a camel, a lion, or a child. The camel symbolizes our being burdened by all the things that come down to us from our customs and traditions, that is to say, when we simply accept everything without questioning anything. The lion symbolizes our being a fighter, that is, when we go against all the things that that our customs and traditions impose on us. The child symbolizes our being innocent again, free from any material, worldly, or even other-worldly concerns. For details, see ibid., 16.

${ }^{107}$ Lee Spinks shares that there are two ways of looking at eternal recurrence: from an existential viewpoint and from a cosmological viewpoint. In this paper, I am adopting the former. See Lee Spinks, Friedrich Nietzsche (London: Routledge, 2003), 126.

${ }^{108}$ Nietzsche first brings up the notion of eternal recurrence in GS, in that section where he lets us imagine a demon who suddenly appears to us during one of our loneliest moments, telling us that our life is an infinite repetitive cycle. For details, see Nietzsche, GS, 273-274. In TSZ, Nietzsche also often brings up the theme of eternal recurrence, especially in Zarathustra's parable of "The Convalescent." See Nietzsche, TSZ, 173-178.

109 Ibid., 174.

110 Ibid., 175.

111 The Blackwell Dictionary of Western Philosophy offers a succinct explanation of the notion of the will to power as Nietzsche describes it in his writings. The will to power is "Nietzsche's term for the most basic human drive to attain a higher and more perfect state, an insatiable desire to manifest power and a drive to employ and exercise power. For him, life itself is the will to

(C) 2018 Alexis Deodato S. Itao

https://www.kritike.org/journal/issue 22/itao june2018.pdf

ISSN 1908-7330

(c) ) BY-NC-ND 
control of your existence and live your life according to how you will it, not according to how things should be as they eternally recur. ${ }^{112}$

\section{The Incarnation of the Free Spirits in the Late Period}

The free spirits still occupy a substantial treatment from Nietzsche in the late period. But in continuation to what he had already begun towards the end of the middle period, he would stick to the concept of overman. TSZ, in fact, ends with a note of hope, announcing the imminent advent of the overman. Through the lips of Zarathustra Nietzsche said, "My children are near, my children."113 The conditions that would favor the incarnation of the free spirits remain unchanged, in spite of Nietzsche's maturation as a philosopher in the late period. They are the same triple dialectic, taken as a continuum, of criticality and openness, unlearning, and relearning, and overcoming and becoming.

\section{A. Between Criticality and Openness: The Incarnation of the Free Spirits in the Late Period}

Nietzsche opened BGE with a harsh criticism against "the prejudices of philosophers," especially metaphysicians. ${ }^{114} \mathrm{He}$ claims that what philosophers christen as "truths" are highly doubtful. An overman should avoid this trap by being very critical, by doubting everything. ${ }^{115}$ Nietzsche would tell us, however, that an overman should not be absolutely critical. It is important to be open that what philosophers consider as mere "appearance" could be the reality, or what they hold as plain "deception" could be the truth. ${ }^{116}$ The overman represents the "new philosophers," and they are coming. ${ }^{117}$ But their way of doing philosophy is different. In

power. This drive is characterized by self-overcoming and ... is life-affirming rather than a desire to dominate others. For Nietzsche, philosophy is the most spiritual expression of the will to power." Nicholas Bunnin and Jiyuan Yu, "Will to Power," in The Blackwell Dictionary of Western Philosophy (Oxford, Blackwell Publishing, 2004), 737.

112 See Eric Oger, "The Eternal Return as a Crucial Test," in Journal of Nietzsche Studies, 14 (1997), 1-18.

${ }^{113}$ Nietzsche, TSZ, 265. Emphasis by Nietzsche.

114 Nietzsche, BGE, 5.

115 Nietzsche uses the Latin expression "de omnibus dubitandum" which means everything is to be doubted. See ibid., 6. This attitude to doubt everything is characteristic of Nietzschean skepticism, which is similar to some extent to the skepticism of the ancient philosophers like Pyrrho (ca. 360-ca. 270 B.C.) and Sextus Empiricus (ca. 160-ca. 210).

116 Ibid.

117 Ibid.

(C) 2018 Alexis Deodato S. Itao

https://www.kritike.org/journal/issue 22/itao june2018.pdf

ISSN 1908-7330 


\section{0}

A CONTINUUM OF TRIPLE DIALECTIC

Nietzsche's own words, they "philosophize with a hammer"118 - that is, with ruthless pounding on established beliefs, teachings, and corpus of knowledge. Still, that doesn't mean that an overman is closed. He is open, ${ }^{119}$ ever willing to see the world with new eyes. ${ }^{120}$

\section{B. Between Unlearning and Relearning: The Second Dialectic in the Late Period}

As we have already shown earlier, the dynamics of becoming an overman does not just involve the dialectic of criticality and openness. Another dialectic-which is that between unlearning and relearning-must come into play. Many of the things that prevent us from becoming who we want to be are rooted in our moral system. These are what we need to unlearn. Hence, Nietzsche brings us back to the genealogy - that is, to the very origins - of our moral concepts. ${ }^{21}$ This will enable us to re-examine and reassess their validity so that, having cleared the dust, we would have a much better look at them. The overman, the free-spirited man, is in many ways a genealogist; he is a fierce critic of established morality. He is an "immoralist" or one of those few "idealists of knowledge in whom alone the intellectual conscience dwells." 122 Thus in GM, Nietzsche argues that we must get rid of the illness called "bad conscience." 123 Precisely, this is done by unlearning everything that we have acquired from it. Bad conscience is teaching us to esteem and practice selflessness, self-denial, and self-sacrifice because these

118 The subtitle of Twilight of the Idols is, Or How to Philosophize with a Hammer. See Friedrich Nietzsche, Twilight of the Idols: Or How to Philosophize with a Hammer, in The Anti-Christ, Ecce Homo, Twilight of the Idols and Other Writings. Henceforth, Twilight of the Idols will be referred to as $T I$.

119 See Friedrich Nietzsche, On the Genealogy of Morals, trans. by Walter Kaufmann and R.J. Hollingdale (New York: Vintage Books, 1967), 38. Henceforth, On the Genealogy of Morals will be referred to as GM.

${ }^{120}$ See Nietzsche, "Morality as Anti-Nature," in TI, § 6.

${ }^{121}$ The concept of genealogy, especially as Nietzsche uses the term in GM, should not be confused with archeology. In Nietzsche, genealogy is a method of historical and axiological critique that questions and examines how our values, beliefs, and concepts of truth and morality originated and emerged in history. Archeology, meanwhile, refers to a form of intellectual excavation that digs deep into the history and origins of certain beliefs and concepts as they emerged in the unconscious. This is how Michel Foucault, and in a way, also Paul Ricoeur, describe archeology in their works. Genealogy and archeology are not really entirely different because they both deal with origins and history, but they should not be confused with one another. For a concise discussion of the distinction between genealogy and archeology, see Mi Gyung Kim, "Archeology, Genealogy, and Geography of Experimental Philosophy," in Social Studies of Science, 0:0 (2013), 1-13.

122 Nietzsche, GM, 149.

${ }^{123}$ Ibid., 88.

(C) 2018 Alexis Deodato S. Itao

https://www.kritike.org/journal/issue 22/itao june2018.pdf

ISSN 1908-7330

(c) $\mathrm{BY}-\mathrm{NC}-\mathrm{ND}$ 
are "beautiful" values. Yet these are all cruelty, Nietzsche would say. ${ }^{124}$ This is why we need to unlearn these dregs of "slave morality." 125 A slave is not a free spirit. He can never be an overman if he remains in that state.

But unlearning is not enough. There should be a revaluation of all values. For Nietzsche, the revaluation of all values is the task of overthrowing all types of morals that originate from "slave morality." His writings in the late period speak a great deal about the necessity and urgency of this task. Such task is meant for us to relearn what values really are. And so, while all unlearning is done, relearning must at the same time be carried out. The dialectic of unlearning and relearning is essential in order for the overman to transform from being a mere ghost into a concrete flesh. But as always, every incarnation of the free spirits requires the dialectic of overcoming and becoming. Here in the late period, Nietzsche remains hopeful that a time will come in the future when the overman will be a reality.

\section{Between Overcoming and Becoming: The Third Dialectic in the Late Period}

Nietzsche recounts in GM that one of the main factors that keep an individual from rising to his freedom and become a free spirit or an overman is the feeling of ressentiment. ${ }^{126}$ In general, ressentiment refers to the feeling of aversion or antipathy towards anything that reflects "master morality" - that is, to the morality that prizes self-control, self-overcoming, self-affirmation, etc. Ressentiment, then, is the feeling that emerges as a reaction against master morality. ${ }^{127}$ It is a "non-reflecting, bitter emotional state" which "creates a feeling of inferiority or impotence." 128 This is why ressentiment is often associated with slave morality; it is simply the opposite of master morality. Since ressentiment gets in the way to liberation, it must be overcome at all cost by exercising the will to power, ${ }^{129}$ by crashing the tendency to adopt the ideals

\footnotetext{
124 Ibid.

${ }^{125}$ In his examination of the genealogy of all morals, Nietzsche traces the origin of all "virtues"-especially those that are esteemed in Christianity like humility, meekness, submissiveness, etc. - to the moral system of slaves, specifically the ancient Jews. Nietzsche stresses that Christianity, as an offshoot of Judaism, has a close resemblance to its mother religion.

126 Ressentiment is a French word which is equivalent to the word "resentment" in English. Nietzsche's use of French is perhaps because for him, no German word can better express what this term really means and suggests.

${ }^{127}$ Nietzche, GM, 36.

128 William L. Remley, "Nietzsche's Concept of Ressentiment as the Psychological Structure for Sartre's Theory of Anti-Semitism," in Journal of European Studies, 46:2 (2016), 4-5.

${ }^{129}$ See Footnote 111.
}

(C) 2018 Alexis Deodato S. Itao

https://www.kritike.org/journal/issue 22/itao june2018.pdf

ISSN 1908-7330 


\section{A CONTINUUM OF TRIPLE DIALECTIC}

of slave morality. As William Remley affirms, "Only by overcoming can a Nietzschean authentic life be achieved." 130

But even the overman, the possessor of master morality, the embodiment of the free spirit and authentic existence, is not a finished business. He must constantly use his will to power to continually overcome himself. As Nietzsche warns, "Whenever the will to power falls off in any way, there will also be physiological decline, decadence."131 Because overcoming is a ceaseless pursuit, becoming is a perpetual endeavor as well. The two always go together. Inasmuch as I overcome, I also become. But I become an overman not when I am restlessly proving my power and prowess to others, not when I boil with rage and throw fierce criticisms towards everything. Rather, I become an overman when at the end I become a lover, when at the end I have amor fati, that is, love for my fate, love for my life. It is a love that lets the overman embrace with openness his eternally recurring fate and lives his life to the maximum, knowing fully well that he has within himself the power to constantly overcome himself. This is the distinguishing trait of every genuine overman. As Nietzsche himself expressed in EC, "My formula for greatness in a human being is amor fati." 132

\section{Taking Inspiration from the Free Spirits}

Having examined most of Nietzsche's works from the early up to the late period, we have seen that the free spirits are not only a recurring, but also a central subject in his philosophy. We can even say that Nietzsche's unique philosophical ideas are closely connected to his concept of the free spirits. If a "Nietzschean utopia" 133 existed in reality, it would most likely be a society of free spirits, a state ruled by a group of, or perhaps just a single, overman. But as I have been arguing throughout this paper, the free spirit or the overman is not a static or fixed reality; he is a continuing process. This implies that Nietzsche's utopia, if it should become a reality, would also be something that is in the constant process of becoming. Whatever the case, I have shown in this paper that for the free spirits to be incarnated in the future, its conditio sine qua non is a long process that employs a continuum of triple dialectic: the dialectics of criticality and openness, unlearning and relearning, and overcoming and becoming.

\footnotetext{
130 Remley, "Nietzsche's Concept of Ressentiment as the Psychological Structure for Sartre's Theory of Anti-Semitism," 10.

${ }^{131}$ Friedrich Nietzsche, The Anti-Christ, in The Anti-Christ, Ecce Homo, Twilight of the Idols and Other Writings, § 17 .

${ }^{132}$ Nietzsche, “Why am I So Clever?" in EC, § 10.

133 Geoff Waite, Nietzsche's Corps/e: Aesthetics, Politics, Prophecy, Or, The Spectacular Technoculture of Everyday Life (London: Duke University Press, 1996), 313.

(C) 2018 Alexis Deodato S. Itao

https://www.kritike.org/journal/issue 22/itao june2018.pdf

ISSN 1908-7330

(c) BY-NC-ND
} 
Nietzsche's free spirits or overman may not yet be a reality-or they may never be a reality at all-but the dynamics through which they will have been incarnated offers plenty of insights on how we may live our lives as "freer" human beings. We may not readily recognize it, but time and again we actually bow down unwillingly to the mighty dictates of customs and traditions. However, if we take some inspiration from the examples of Nietzsche's free spirits, we can take comfort at the thought that what's more important in life is not whether we have followed or disobeyed some rules or norms. What is always important is whether we are happy with the fact that what we have, where we are, and what we have become is not the end-all and be-all of our existence. Finally, in our present capitalist-dominated and technologically-mediated world, many of us have been enslaved by lust for money, materialism, and even by technology itself. In a way, we are not truly free. But if we take inspiration again from Nietzsche's free spirits, we can always overcome all these obstacles that keep us from rising above our current conditions. After all, we have within us all the power to assert ourselves and affirm our freedom. We have all the potential to become free spirits. The question is not how, but when.

\section{Department of Social Sciences, College of Arts and Sciences Cebu Normal University, Philippines}

\section{References}

Bailey, Tom, Review of Nietzsche: His Philosophy of Contradictions and the Contradictions of His Philosophy, by Wolfgang Müller-Lauter, in Journal of Nietzsche Studies, 25 (2003).

Beiser, Frederick C., "Introduction: Hegel and the Problem of Metaphysics," in The Cambridge Companion to Hegel, ed. by Frederick C. Beiser (Cambridge: Cambridge University Press, 1993).

Beverluis, John, "Socrates," in The World's Great Philosophers, ed. by Robert L. Arrington (Oxford: Blacwell Publishing, 2003).

Bogue, Ronald, Deleuze and Guattari (London: Routledge, 1991).

Bunnin, Nicholas and Jiyuan Yu, "Will to Power," in The Blackwell Dictionary of Western Philosophy (Oxford, Blackwell Publishing, 2004).

Bolaños, Paolo A., On Affirmation and Becoming: A Deleuzian Introduction to Nietzsche's Ethics and Ontology (Newcastle upon Tyne: Cambridge Scholars Publishing, 2014).

Cauchi, Francesca, "Hegel and Nietzsche on Thought, Freedom, and "The Labour of the Negative'," in Journal of European Studies, 46:2 (2016).

Deleuze, Gilles, Nietzsche and Philosophy, trans. By Hugh Tomlinson (New York: Columbia University Press, 2006).

(C) 2018 Alexis Deodato S. Itao

https://www.kritike.org/journal/issue 22/itao june2018.pdf

ISSN 1908-7330

(cc) BY-NC-ND 


\section{A CONTINUUM OF TRIPLE DIALECTIC}

D'Iorio, Richard, Nietzsche's Journey to Sorrento: Genesis of the Philosophy of the Free Spirits, trans. by Sylvia Mae Gorelick (Chicago: University of Chicago Press, 2016).

Dudley, Will, Hegel, Nietzsche, and Philosophy: Thinking Freedom (Cambridge: Cambridge University Press, 2002).

Forster, Michael, "Hegel's Dialectical Method," in The Cambridge Companion to Hegel, ed. by Frederick C. Beiser (Cambridge: Cambridge University Press, 1993).

Franco, Paul, Nietzsche's Enlightenment: Free-Spirit Trilogy of the Middle Period (Chicago: University of Chicago Press, 2011).

Golomb, Jakob, "Will to Power: Does It Lead to the 'Coldest of All Cold Monsters'?" in The Oxford Handbook of Nietzsche, ed. by Ken Gemes and John Richardson (Oxford: Oxford University Press, 2013).

Hollinrake, Roger, Nietzsche, Wagner, and the Philosophy of Pessimism (New York: Routledge, 2010).

Hough, Sheridan, Nietzsche's Noontide Friend: The Self as Metaphoric Double (Pennsylvania: The Pennsylvania State University Press, 1997).

Howey, Richard Lowel, Heidegger and Jaspers on Nietzsche: A Critical Examination of Heidegger's and Jaspers' Interpretation of Nietzsche (The Hague: Martinus Nijhoff, 1973)

Jackson, Jeffrey M., Suffered and Social Histories: Genealogy and Convalescence (New York: Palgrave Macmillan, 2017).

Kaufmann, Walter A., Nietzsche: Philosopher, Psychologist, Antichrist, $4^{\text {th }}$ ed. (Princeton: Princeton University Press, 2013).

"Nietzsche's Admiration for Socrates," in Journal of the History of Ideas, 9:4 (October 1948).

Kim, Mi Gyung, "Archeology, Genealogy, and Geography of Experimental Philosophy," in Social Studies of Science, 0:0 (2013).

Kullmann, Wolfgang, "Aristotle's Gradual Turn from Dialectic," in The Development of Dialectic from Plato to Aristotle, ed. by Jakob Lith Fink (Cambridge: Cambridge University Press, 2012).

Llewelyn, John, Margins of Religion: Between Kierkegaard and Derrida (Bloomington: Indiana University Press, 2009).

Mitcheson, Katrina, Nietzsche, Truth and Transformation (London: Palgrave Macmillan, 2013).

Nehamas, Alexander, Nietzsche: Life as Literature (Cambridge, Massachusetts: Harvard University Press, 1985).

Nietzsche, Friedrich, Anti-Education: On the Future of Our Educational Institutions, trans. by Damion Searls, ed. by Paul Reitter and Chad Wellmon (New York: The New York Review of Books, 2016).

(C) 2018 Alexis Deodato S. Itao

https://www.kritike.org/journal/issue 22/itao june2018.pdf

ISSN 1908-7330

(c) BY-NC-ND 
Beyond Good and Evil, ed. by Rolf-Peter Horstmann and Judith Norman, trans. by Judith Norman (New York: Cambridge University Press, 2002). Daybreak: Thoughts on the Prejudices of Morality, ed. by Maudemarie Clark and Brian Leiter, trans. by R.J. Hollingdale (Cambridge: Cambridge University Press, 1997). Human All Too Human: A Book for Free Spirits, trans. by R. J. Hollingdale (Cambridge: Cambridge University Press, 1986). On the Genealogy of Morals, trans. by Walter Kaufmann and R.J. Hollingdale (New York: Vintage Books, 1967). The Anti-Christ, Ecce Homo, Twilight of the Idols, and Other Writings, ed. by Aaron Ridley and Judith Norman, trans. by Judith Norman (Cambridge: Cambridge University Press, 2005).

The Birth of Tragedy and Other Writings, trans. by Raymond Guess and Ronald Speirs (Cambridge: Cambridge University Press, 1999).

The Gay Science, trans. by Walter Kaufmann (New York: Vintage Books, 1974). The Portable Nietzsche, ed. and trans. by Walter A. Kaufmann (London: Penguin Books, 1954). The Will to Power, ed. by Oscar Levy and trans. by Anthony M. Ludovici (New York: Gordon Press, 1974). Thus Spoke Zarathustra, ed. by Adrian Del Caro and Robert Pippin, trans. by Adrian Del Caro (Cambridge: Cambridge University Press, 2006). Unfashionable Observations, trans. by Richard T. Gray (Stanford, California: Stanford University Press, 1995).

Oger, Eric, "The Eternal Return as a Crucial Test," in Journal of Nietzsche Studies, 14 (1997).

Pearson, Keith Ansell, "Friedrich Nietzsche: An Introduction to his Thought, Life, and Work," in A Companion to Nietzsche, ed. by Keith Ansell Pearson (Victoria, Australia: Blackwell Publishing, 2006).

Pfeffer, Rose, Nietzsche: Disciple of Dionysius (Cranbury: Associated University Presses, 1972).

Remley, William L., "Nietzsche's Concept of Ressentiment as the Psychological Structure for Sartre's Theory of Anti-Semitism," in Journal of European Studies, 46:2 (2016).

Richardson, John, Nietzsche's New Darwinism (Oxford: Oxford University Press, 2004). Nietzsche's System (Oxford: Oxford University Press, 1996).

Singer, Peter, Marx: A Very Short Introduction (Oxford: Oxford University Press, 1996).

Spinks, Lee, Friedrich Nietzsche (London: Routledge, 2003).

(C) 2018 Alexis Deodato S. Itao https://www.kritike.org/journal/issue 22/itao june2018.pdf ISSN 1908-7330 


\section{A CONTINUUM OF TRIPLE DIALECTIC}

Sommer, Andreas Urs, "Nihilism and Skepticism in Nietzsche," in A Companion to Nietzsche, ed. by Keith Ansell Pearson (Victoria, Australia: Blackwell Publishing, 2006).

Waite, Geoff, Nietzsche's Corps/e: Aesthetics, Politics, Prophecy, Or, The Spectacular Technoculture of Everyday Life (London: Duke University Press, 1996).

Wetstein, Brian, "The Role of Dialectic in Nietzsche's Thought" (Ph.D. Dissertation, University of Guelp, 1994). 